\title{
Manifestation features of the productivity potential of Salvia officinalis $L$. in the conditions of the Crimea foothills
}

\author{
Natalia Nevkrytaya*, Ilja Novikov, Elena Soboleva, Natalia Kashirina, and Ludmila \\ Radchenko \\ Research Institute of Agriculture of Crimea (RIAC), 150 Kievskaya street, 295493.Simferopol, \\ Russian Federation
}

\begin{abstract}
The research objective is to identify the manifestation features of the productivity potential of Salvia officinalis L. in the conditions of the Crimea Foothills. The study was carried out in 2017-2019 on the Kubanets variety (selection of All-Russian Scientific Research Institute of Medicinal and Aromatic Plants) and the population of the Institute of Essential Oil and Medicinal Plants (IELR) in the scientific crop rotation of the Research Institute of Agriculture of Crimea (Belogorsky district). The analysis of samples for a complex of features was performed according to the method, including statistical data processing. The yield of the green mass of the Kubanets variety and the IELR population was, on average, $24.2 \pm 1.6$ and $26.5 \pm 2.1 \mathrm{t} / \mathrm{ha}$, the crop of essential oil was $29.5 \pm 3.7$ and $34.2 \pm 4.2 \mathrm{~kg} / \mathrm{ha}$, respectively. In the conditions of extreme drought and high temperature conditions in 2018, the advantage of the IELR population in terms of raw materials content and essential oil collection was revealed, which indicates that it is more adapted to the conditions of the region. When air-dry raw material without stems stored for up to 12 months, the content of essential oil does not decrease and is $1.00-1.10 \%$ in the Kubanets variety and 1.05 $1.15 \%$ in the IELR population. The component composition of the essential oil samples meets the requirements of ISO 9909:1997.
\end{abstract}

\section{Introduction}

Salvia officinalis L. is a perennial plant in the Lamiaceae family. Due to the presence of valuable biologically active substances in plant raw materials, including essential oil, $S$. officinalis is widely used in official medicine as an anti-inflammatory and antimicrobial agent for the treatment of the throat, oral cavity, ulcers, etc. [1,2]. S. officinalis has astringent, choleretic, antispasmodic, stimulating and tonic properties. Numerous studies have shown the antibiotic, antibacterial and antimicrobial activity of its essential oil. The plant is used in the treatment of diseases of the musculoskeletal system, colds, gynecological diseases and early stages of cancer $[3,4]$. Cytotoxical analyses of tumors (Hep-2, HeLa, A-549, HT-29, and A-375) showed selectivity of aqueous and water-alcohol

\footnotetext{
${ }^{*}$ Corresponding author: nevkritaya@mail.ru
} 
extracts of S. officinalis against tumor cells [5]. It was found that the extract from the leaves of this plant shows antimicrobial activity against Staphylococcus aureus, B. subtilis, $S$. pyogenosa and Candida albicans. This suggests the possibility of creating new antibacterial agents based on it [6].

Researchers from Tunisia noted insecticidal activity of $S$. officinalis essential oil against Spodoptera littoralis larvae and adult Tribolium castaneum specimen with LC50 values of 55.99 and $97.43 \mu 1 / 1$ of air, respectively [7].

The "State Register of Selection Achievements Authorized for Use for Production Purposes" of the Russian Federation includes three varieties of $S$. officinalis, including the Kubanets variety selected by the All-Russian Scientific Research Institute of Medicinal and Aromatic Plants (VILAR) [8].

When creating varieties of agricultural plants, selection work is carried out in specific soil and climatic conditions. Accordingly, the given characteristics of the variety's productivity are relevant for its cultivation in this region. In order to clarify the optimal conditions that ensure the maximum manifestation of the variety's potential, its environmental testing is carried out in regions that differ in the peculiarities of climatic conditions [9-11].

The research objective is to identify the manifestation features of the productivity potential of $S$. officinalis in the climatic conditions of the Crimea Foothills.

\section{Materials and methods of research}

The productivity of $S$. officinalis was studied in 2017-2019. The study was carried out on the Kubanets variety (VILAR selection) in comparison with the IELR population (from the collection of the Research Institute of Agriculture of Crimea (RIAC) at the experimental site of the RIAC Department of essential oil and medicinal crops (Krymskaya Roza village, Belogorsky district, Crimea). The climate of the region is moderately continental. The territory belongs to one of the five agroclimatic regions - the upper foothill, warm, insufficiently humid; the Northern subdistrict with moderately mild winter [12].

Seeding was carried out on 31.03.2016. Each sample is placed on five single-row plots $5 \mathrm{~m}$ long. Row spacing - $0.6 \mathrm{~m}$. On the plot - $14-15$ plants. The analysis of morphobiological parameters and productivity indicators was carried out at the stage of the flowering end - the beginning of fruit formation in 3 repetitions in accordance with the guidelines [13]. The content of essential oil in the raw material and its component composition were determined [14,15]. Chromatographic analysis of the component composition of the essential oil was performed on a gas chromatograph, model Crystal 5000.2, under the following technical conditions: carrier gas - grade A helium; detector type - flame ionization; capillary column CR-WAXms, size $30 \mathrm{~m} \times 0.32 \mathrm{~mm}$; thickness of the stationary phase layer - 0.5 microns; detector temperature - $250^{\circ} \mathrm{C}$; evaporator temperature $-230^{\circ} \mathrm{C}$; carrier gas consumption $-1.9 \mathrm{ml} / \mathrm{min}$. The initial temperature of the column is $75^{\circ} \mathrm{C}$ with a 1 minute exposure time; heating speed $4^{\circ} \mathrm{C} / \mathrm{min}$; final column temperature $220^{\circ} \mathrm{C}$ without exposure; analysis duration - 37.3 minutes; split ratio 1:20.

Quantitative data were statistically processed in accordance with the field experience methodology using the Microsoft Office Excel 2007 software package [16].

\section{Results and their discussion}

Hydrothermal conditions in 2017 (sufficient precipitation and temperatures close to the long-term average values) were favorable for the development of S. officinalis. In 2018, the temperature regime during the active vegetation period of plants from the regrowth phase to 
the end of flowering was characterized by higher indicators compared to the same period in 2017. In terms of precipitation, spring and early summer were extremely dry. Intermediate weather conditions were 2019, dry in the spring, hot in June, with sufficient precipitation in the 2 nd half of the month. A large amount of precipitation fell in early July, but the temperature was slightly below normal.

Features of weather conditions in the years of research led to differences in the timing of the main phenological phases of plant development (table 1). There were no differences between the studied samples.

Table 1. Time of occurrence of the main phenological phases of S. officinalis development.

\begin{tabular}{|c|c|c|c|c|c|}
\hline \multicolumn{3}{|c|}{ Beginning of regrowth } & \multicolumn{3}{c|}{ Accounting } \\
\hline 2017 & 2018 & 2019 & 2017 & 2018 & 2019 \\
\hline 02.04 & 06.03 & 26.04 & 15.06 & 29.05 & 17.06 \\
\hline
\end{tabular}

The results of studying the morphobiological parameters and structure of raw materials of the Kubanets variety and the IELR population are shown in table 2.

Table 2. Characteristics of morphobiological parameters and structure of S. officinalis raw materials.

\begin{tabular}{|c|c|c|c|c|c|}
\hline \multirow{4}{*}{$\begin{array}{c}\text { Variety } \\
\text { sample }\end{array}$} & Year & $\begin{array}{c}\text { Plant } \\
\text { height, cm }\end{array}$ & $\begin{array}{c}\text { Ratio of air-dry } \\
\text { mass of raw } \\
\text { materials to the } \\
\text { mass of fresh raw } \\
\text { materials, \% }\end{array}$ & $\begin{array}{c}\text { Proportion of } \\
\text { inflorescences and } \\
\text { leaves in the total } \\
\text { mass of fresh raw } \\
\text { materials, \% }\end{array}$ & $\begin{array}{c}\text { Proportion of } \\
\text { inflorescences and } \\
\text { leaves in the total } \\
\text { mass of air-dry } \\
\text { raw materials, \% }\end{array}$ \\
\hline \multirow{4}{*}{ Kubanets } & 2017 & $86.0 \pm 2.8$ & 19.8 & 52.5 & 48.5 \\
\cline { 2 - 6 } & 2018 & $72.0 \pm 1.2$ & 21.8 & 48.5 & 53.8 \\
\cline { 2 - 6 } & 2019 & $75.7 \pm 1.7$ & 32.5 & 48.5 & 45.7 \\
\cline { 2 - 6 } & average & $\mathbf{7 7 . 9} \pm \mathbf{4 . 2}$ & $\mathbf{2 4 . 7}$ & $\mathbf{4 9 . 8}$ & $\mathbf{4 9 . 3}$ \\
\hline \multirow{3}{*}{$\begin{array}{c}\text { IELR } \\
\text { population }\end{array}$} & 2017 & $84.5 \pm 1.6$ & 21.0 & 50.2 & 47.5 \\
\cline { 2 - 6 } & 2018 & $72.5 \pm 1.1$ & 24.1 & 50.8 & 53.8 \\
\cline { 2 - 6 } & 2019 & $77.7 \pm 2.1$ & 28.8 & 50.8 & 46.2 \\
\cline { 2 - 6 } & average & $\mathbf{7 8 . 2} \pm \mathbf{3 . 5}$ & $\mathbf{2 4 . 6}$ & $\mathbf{5 0 . 6}$ & $\mathbf{4 9 . 2}$ \\
\hline
\end{tabular}

The plants of both samples reached the highest height in favorable conditions in 2017. In 2018-2019, the height of plants was significantly lower, due to difficult weather conditions for the development of S. officinalis. When fresh S. officinalis raw materials are dried to an air-dry state, the mass decreases, on average, by five times. The proportion of inflorescences and leaves in the total mass of both fresh and air-dry raw materials of both samples is about $50 \%$.

Productivity indicators are particularly important for agricultural producers growing $S$. officinalis. The total weight and weight without stems of fresh and air-dry raw materials were analyzed (table 3).

Under favorable conditions in 2017 , the highest yield of raw materials for both studied $S$. officinalis samples was achieved. The IELR population significantly exceeded the Kubanets variety in terms of yield of total weight and weight without stems: fresh raw materials - by 17.9 and $11.0 \%$, air-dry raw materials - by 23.6 and $23.1 \%$.

In the conditions of extremely dry and hot 2018 , the samples did not significantly differ in the yield of raw materials. However, there is a tendency for this indicator to exceed the Kubanets variety by the IELR population. In terms of the content in raw materials and crop of essential oil in all variants, the IELR population significantly exceeded the Kubanets variety. In 2019, there were no differences between the samples in terms of productivity. 
Analysis of air-dry raw materials without stems after 3, 6 and 12 months of storage showed that the essential oil content in it does not decrease and is $1.00-1.10 \%$ in the Kubanets variety and $1.05-1.15 \%$ in the IELR population.

Table 3. Characteristics of economically valuable indicators of the Kubanets variety and the IELR population of S. officinalis

\begin{tabular}{|c|c|c|c|c|c|c|c|c|}
\hline \multirow[b]{2}{*}{$\begin{array}{l}\text { Variety } \\
\text { sample }\end{array}$} & \multirow[b]{2}{*}{$\begin{array}{c}\text { Raw } \\
\text { materials } \\
\text { structure }\end{array}$} & \multicolumn{2}{|c|}{$\begin{array}{l}\text { Yield of green } \\
\text { mass, } t / \text { ha }\end{array}$} & \multicolumn{3}{|c|}{ Mass fraction of essential oil, $\%$} & \multicolumn{2}{|c|}{$\begin{array}{l}\text { Essential oil crop, } \\
\mathrm{kg} / \mathrm{ha}\end{array}$} \\
\hline & & $\begin{array}{l}\text { fresh raw } \\
\text { materials }\end{array}$ & $\begin{array}{l}\text { air-dry } \\
\text { raw } \\
\text { mate- } \\
\text { rials }\end{array}$ & $\begin{array}{l}\text { in fresh } \\
\text { raw } \\
\text { materials }\end{array}$ & $\begin{array}{c}\text { in absolute } \\
\text { dry raw } \\
\text { materials }\end{array}$ & $\begin{array}{c}\text { in air-dry } \\
\text { raw } \\
\text { materials }\end{array}$ & $\begin{array}{c}\text { from fresh } \\
\text { raw } \\
\text { materials }\end{array}$ & $\begin{array}{l}\text { from air- } \\
\text { dry raw } \\
\text { materials }\end{array}$ \\
\hline \multicolumn{9}{|c|}{2017} \\
\hline Kubanets & \multirow{2}{*}{$\begin{array}{c}\text { total mass } \\
\text { of raw } \\
\text { materials }\end{array}$} & $27.4 \pm 1.0$ & $5.5 \pm 0.3$ & $0.15 \pm 0.00$ & $0.92 \pm 0.00$ & $0.50 \pm 0.00$ & $41.2 \pm 1.4$ & $27.3 \pm 1.5$ \\
\hline $\begin{array}{c}\text { IELR } \\
\text { population }\end{array}$ & & $32.3 \pm 0.7$ & $6.8 \pm 0.1$ & $0.14 \pm 0.01$ & $0.85 \pm 0.08$ & $0.50 \pm 0.00$ & $44.5 \pm 1.5$ & $33.7 \pm 0.4$ \\
\hline Kubanets & \multirow{2}{*}{$\begin{array}{c}\text { mass } \\
\text { without } \\
\text { stems }\end{array}$} & $14.5 \pm 0.7$ & $2.6 \pm 0.1$ & $0.24 \pm 0.01$ & 1.46 & 0.07 & $34.5 \pm 2.8$ & $30.7 \pm 1.9$ \\
\hline $\begin{array}{c}\text { IELR } \\
\text { population }\end{array}$ & & $16.1 \pm 0.5$ & $3.2 \pm 0.1$ & $0.20 \pm 0.00$ & $1.23 \pm 0.00$ & $1.39 \pm 0.11$ & $32.3 \pm 1.0$ & $44.1 \pm 0.5$ \\
\hline \multicolumn{9}{|c|}{2018} \\
\hline Kubanets & \multirow{2}{*}{$\begin{array}{c}\text { total mass } \\
\text { of raw } \\
\text { materials }\end{array}$} & $26.8 \pm 1.6$ & $5.9 \pm 0.8$ & $0.12 \pm 0.01$ & $0.68 \pm 0.05$ & $0.64 \pm 0.01$ & $31.2 \pm 2.3$ & $37.3 \pm 4.3$ \\
\hline $\begin{array}{c}\text { IELR } \\
\text { population }\end{array}$ & & $28.7 \pm 1.8$ & $6.9 \pm 0.3$ & $0.14 \pm 0.01$ & $0.83 \pm 0.05$ & $0.69 \pm 0.01$ & $40.3 \pm 0.4$ & $47.6 \pm 2.3$ \\
\hline Kubanets & \multirow{2}{*}{$\begin{array}{c}\text { mass } \\
\text { without } \\
\text { stems }\end{array}$} & $13.1 \pm 1.2$ & $3.2 \pm 0.5$ & $0.26 \pm 0.01$ & $1.52 \pm 0.05$ & $1.18 \pm 0.04$ & $33.6 \pm 2.1$ & $37.5 \pm 4.1$ \\
\hline $\begin{array}{c}\text { IELR } \\
\text { population }\end{array}$ & & $14.6 \pm 1.0$ & $3.7 \pm 0.1$ & $\mathbf{0 . 3 0} \pm \mathbf{0 . 0 0}$ & $1.77 \pm 0.00$ & $1.48 \pm 0.02$ & $43.7 \pm 3.0$ & $54.5 \pm 2.5$ \\
\hline \multicolumn{9}{|c|}{2019} \\
\hline Kubanets & \multirow{2}{*}{$\mid \begin{array}{c}\text { total mass } \\
\text { of raw } \\
\text { materials }\end{array}$} & $18.3 \pm 1.0$ & $5.9 \pm 0.3$ & $0.09 \pm 0.01$ & $0.35 \pm 0.03$ & $0.45 \pm 0.09$ & $16.0 \pm 1.2$ & $26.8 \pm 5.1$ \\
\hline $\begin{array}{c}\text { IELR } \\
\text { population } \\
\end{array}$ & & $18.6 \pm 0.7$ & $5.4 \pm 0.3$ & $0.10 \pm 0.00$ & $0.38 \pm 0.02$ & $0.37 \pm 0.00$ & $17.9 \pm 0.2$ & $19.9 \pm 2.0$ \\
\hline Kubanets & \multirow{2}{*}{$\begin{array}{c}\text { mass } \\
\text { without } \\
\text { stems }\end{array}$} & $9.1 \pm 0.7$ & $2.7 \pm 0.3$ & $0.20 \pm 0.00$ & $0.81 \pm 0.03$ & $1.07 \pm 0.10$ & $18.6 \pm 1.1$ & $28.6 \pm 0.1$ \\
\hline \begin{tabular}{c|} 
IELR \\
population
\end{tabular} & & $9.4 \pm 0.5$ & $2.5 \pm 0.1$ & $0.22 \pm 0.01$ & $0.83 \pm 0.03$ & $0.90 \pm 0.06$ & $20.2 \pm 0.8$ & $22.4 \pm 0.9$ \\
\hline \multicolumn{9}{|c|}{ on average for the $2017-2019$} \\
\hline Kubanets & \multirow{2}{*}{$-\begin{array}{c}\text { total mass } \\
\text { of raw } \\
\text { materials }\end{array}$} & $24.2 \pm 1.6$ & $5.8 \pm 0.3$ & $0.12 \pm 0.01$ & $0.68 \pm 0.09$ & $0.53 \pm 0.04$ & $29.5 \pm 3.7$ & $30.5 \pm 2.6$ \\
\hline $\begin{array}{c}\text { IELR } \\
\text { population }\end{array}$ & & $26.5 \pm 2.1$ & $6.3 \pm 0.3$ & $0.13 \pm 0.01$ & $0.69 \pm 0.08$ & $0.52 \pm 0.05$ & $34.2 \pm 4.2$ & $33.8 \pm 4.1$ \\
\hline Kubanets & \multirow{2}{*}{$\begin{array}{c}\text { mass } \\
\text { without } \\
\text { stems }\end{array}$} & $12.2 \pm 1.0$ & $2.9 \pm 0.2$ & $0.23 \pm 0.01$ & $1.26 \pm 0.12$ & $1.14 \pm 0.04$ & $28.7 \pm 2.8$ & $32.4 \pm 1.9$ \\
\hline $\begin{array}{c}\text { IELR } \\
\text { population }\end{array}$ & & $13.3 \pm 1.1$ & $3.1 \pm 0.2$ & $0.24 \pm 0.02$ & $1.27 \pm 0.14$ & $1.25 \pm 0.09$ & $32.0 \pm 3.5$ & $40.0 \pm 4.8$ \\
\hline
\end{tabular}

The biological properties of essential oil are determined by the ratio of its main and minor components. Analysis of literature data shows that the component composition of $S$. officinalis essential oil is sufficiently studied [17]. However, the qualitative and quantitative composition of essential oil depends on many factors, including plant growth conditions [7,18-20]. In the literature, there is information about the existence of different chemotypes of $S$. officinalis. Cluster analysis of the component composition of 185 essential oil samples revealed five main chemotypes. Most of them belong to the chemotype: thujone-camphor1,8-cineole [21]. Different chemotypes of $S$. officinalis essential oil may differ not only in 
flavor, but also in biological activity. Therefore, special attention in our research was paid to the analysis of the component composition of the essential oil of both studied samples.

The analysis of the component composition of essential oil from the total mass and the mass without stems of both fresh and air-dry raw materials was carried out (table 4).

Table 4. The content of the main components in S. officinalis essential oil of the Kubanets variety and the IELR population.

\begin{tabular}{|c|c|c|c|c|c|c|c|c|c|}
\hline \multirow[b]{2}{*}{ Sample } & \multirow[b]{2}{*}{ Year } & \multicolumn{8}{|c|}{ Main components of essential oil, $\%$} \\
\hline & & $\begin{array}{c}1.8 \\
\text { cineole }\end{array}$ & $\begin{array}{l}\alpha-\text { and } \beta- \\
\text { thujones }\end{array}$ & ce & $\begin{array}{c}\text { caryo- } \\
\text { phyllene }\end{array}$ & $\begin{array}{c}\alpha \text {-humu- } \\
\text { lene }\end{array}$ & $\begin{array}{l}\alpha \text {-terpi- } \\
\text { neole }\end{array}$ & viridi- & epi- \\
\hline \multicolumn{10}{|c|}{ essential oil from the total mass of fresh raw materials } \\
\hline \multirow{4}{*}{$\begin{array}{c}\text { Kuba- } \\
\text { nets } \\
\text { variety }\end{array}$} & & \pm 0.3 & $14.1 \pm 0.9$ & $2.9 \pm 0.3$ & & $8.8 \pm 01$ & \pm 0.0 & & \\
\hline & & & & & & & & & \\
\hline & 19 & & & & & & & & \\
\hline & average & & & & & & & & \\
\hline \multirow{4}{*}{$\begin{array}{l}\text { IELR } \\
\text { popu- } \\
\text { lation }\end{array}$} & & & & & & & & & \\
\hline & & & & & & & & & \\
\hline & 2019 & & & & & & & & \\
\hline & iverage & & & 8 & & & & & \\
\hline \multicolumn{10}{|c|}{ essential oil from the total mass of fresh raw materials without stems } \\
\hline \multirow{4}{*}{$\begin{array}{c}\text { Kuba- } \\
\text { nets } \\
\text { variety }\end{array}$} & & & & $2.9 \pm 0.4$ & & & $8.5 \pm 0.2$ & & \\
\hline & 21 & & & & & & & & \\
\hline & 2019 & & & & & & & & \\
\hline & & & & & & & & & \\
\hline \multirow{4}{*}{$\begin{array}{l}\text { IELR } \\
\text { popu- } \\
\text { lation }\end{array}$} & & & & & & & & & \\
\hline & & & & & & & & & \\
\hline & & & & & & & & & \\
\hline & & \pm 1.0 & & & & & & & \\
\hline \multicolumn{10}{|c|}{ essential oil from the total ma } \\
\hline \multirow{4}{*}{$\begin{array}{l}\text { Kuba- } \\
\text { nets } \\
\text { variety }\end{array}$} & & & & & & & & & \\
\hline & & & & & & & & & \\
\hline & & & & & & & & & \\
\hline & & & & & & & & & \\
\hline \multirow{4}{*}{$\begin{array}{l}\text { IELR } \\
\text { popu- } \\
\text { lation }\end{array}$} & & & & & & & & & \\
\hline & & & & & & & & & \\
\hline & 2019 & & & & & & & & \\
\hline & iverage & $9.4 \pm 2.0$ & & 4.5 & & 6.4 & 1.6 & $11.3 \pm 2.5$ & \\
\hline \multicolumn{10}{|c|}{ terials without sten } \\
\hline \multirow{4}{*}{$\begin{array}{c}\text { Kuba- } \\
\text { nets } \\
\text { variety }\end{array}$} & & & & & & & & & \\
\hline & & & & & & & & & \\
\hline & 2019 & & & & & & & & \\
\hline & & & & & & & & & \\
\hline \multirow{4}{*}{$\begin{array}{l}\text { IELR } \\
\text { popu- } \\
\text { lation }\end{array}$} & & & & & & & & & \\
\hline & & & & & & & & & \\
\hline & & & & & & & & & \\
\hline & average & $12.6 \pm 0.6$ & $23.5 \pm 0.3$ & $4.3 \pm 1.1$ & $11.3 \pm 0.9$ & $5.4 \pm 0.4$ & $4.3 \pm 1.9$ & & \\
\hline \multicolumn{10}{|c|}{ onths of storag } \\
\hline \multirow{3}{*}{$\begin{array}{l}\text { Kuba- } \\
\text { nets } \\
\text { variety }\end{array}$} & & & & & & & & & \\
\hline & 2019 & & & & & & & & \\
\hline & & & & & & & & & \\
\hline \multirow{3}{*}{$\begin{array}{l}\text { IELR } \\
\text { popu- } \\
\text { lation }\end{array}$} & & & & & & & & & \\
\hline & 2019 & & & $5.4=$ & & & & & 0. \\
\hline & average & $12.7 \pm 0.6$ & $24.6 \pm 0.7$ & $5.3 \pm 0.1$ & $10.6 \pm 0.9$ & $5.3 \pm 0.2$ & $7.0 \pm 0.3$ & $9.7 \pm 0.8$ & $3.8 \pm 1.1$ \\
\hline
\end{tabular}


Comparison of the obtained data suggests that there are no significant differences in the component composition of $S$. officinalis essential oil of the Kubanets variety and the IELR population. However, for both samples, the content of a number of components in the essential oil from the total mass of fresh raw materials and from fresh raw materials without stems differed. Thus, the essential oil from fresh raw materials without stems of the Kubanets variety contains, on average, 109.1\% more 1.8-cineole (eucalyptole) and 16.3\% more thujones, and in the IELR population - 140.9 and $46.4 \%$, respectively, compared to the essential oil from the total mass of fresh raw materials. At the same time, such components as viridiflorol and epimanool are contained in essential oil from fresh raw materials without stems in smaller amounts: from the Kubanets variety, respectively, by 59.6 and $48.2 \%$, and from the IELR population - by 61.9 and $10.0 \%$, respectively. There were no significant differences in the component composition of essential oil from air-dry raw materials.

Comparison of essential oil components ratio in various hydrothermal conditions showed that thujone accumulation was more active in extremely hot and arid conditions in 2018. Higher camphor content was observed in 2018 and 2019.

The conditions of increased precipitation and moderate temperature conditions in 2017 were more favorable for the accumulation of other components.

The lowest dependence on hydrothermal conditions of the year was observed for the accumulation of epimanool, and the highest - for $\alpha$-terpineole. Thus, in extreme conditions in 2018, $\alpha$-terpineole was part of the essential oil in minor amounts $-0.2-0.3 \%$, while in 2017 and 2019 it was contained in an amount from 5.3 to $14.5 \%$.

By its component composition, the essential oil of both the Kubanets variety and the $S$. officinalis IELR population meets the ISO 9909:1997 standard [22].

When analyzing the component composition of $S$. officinalis essential oil of both samples, obtained from raw materials without stems and stored for a year, there were no differences between the studied samples. It should be emphasized that the ratio of components during storage of essential oil has not changed significantly.

\section{Conclusions}

1. A comparative study of the productivity indicators of S. officinalis of the Kubanets variety and the IELR population during cultivation in the Crimea Foothills for three years showed that there were no stable reliable differences by all analyzed indicators.

2. The advantage of the IELR population above Kubanets variety by content in raw materials and essential oil crop under conditions of extreme drought and high temperature regime indicates its greater adaptability to the conditions of the region.

3. The estimated crop of essential oil from the total mass of fresh raw materials of the Kubanets variety and the IELR population is on average $29.5 \pm 3.7$ and $34.2 \pm 4.2 \mathrm{~kg} / \mathrm{ha}$, from air-dry raw materials $-30.5 \pm 2.6$ and $33.8 \pm 4.1 \mathrm{~kg} / \mathrm{ha}$, respectively.

4. Analysis of air-dry raw materials without stems after 3, 6 and 12 months of storage showed that the essential oil content in it does not decrease and is $1.00-1.10 \%$ in the Kubanets variety and $1.05-1.15 \%$ in the IELR population.

5. The component composition of the essential oil of both analyzed samples does not differ significantly and meets the requirements of the ISO 9909:1997 standard.

\section{References}

1. I. Zilfikarov, Bull. S.-P., Med. 3 (2007)

2. S. Chuikin, N. Kudashkina, R. Galeeva, Med. Bull. Bash., 9, 6 (2014) 
3. Ghorbani, M. Esmaeilizadeh, J. Tradit. Complement. Med., 7, 4 (2017)

4. G. Privitera, S. Castorina, R. Passanisi, E. Napoli, Asian Pac. J. Trop. Biomed., 9, 1 (2019)

5. C. Garcia, C. Menti, A. Lambert, T. Barcellos, An. Acad. Bras. Ciênc., 88 (2016)

6. O. Koshoviy, E. Perederiy, O. Gudzenko, A. Kovalova, A. Komisarenko, Ukr. J. Clin. Lab. Med., 5, 1 (2010)

7. M. Ben Khedher, S. Ben Khedher, I. Chaieb, S. Tounsi, M. Hammam, EXCLI J., 16 (2017)

8. State Register of Selection Achievements Authorized for Use for Production Purposes Volume 1. Plant varieties (as of March 12, 2020), URL: https://gossortrf.ru/wpcontent/uploads/2020/03/FIN_reestr_dop_12_03_2020.pdf.

9. F. Fefelov, V. Pronkin, E. Kashnova, O. Razin, Bull. BSAU, 2, 26 (2013)

10. L. Pecetti, A. Marcotrigiano, L. Russi, M. Romani, P. Annicchiarico, Crop Pasture Sci., 70, 4 (2019)

11. R. Weber, K. Nowosad, H. Bujak, E. Gacek, Pol. J. Natur. Sc. 32, 2 (2017)

12. L. Savchuk, Climate of Crimean foothills and essential-oil-bearing plants (Simferopol, 2006)

13. Essential oil crops breeding (guidelines), Ed. by Arinshteyn A.I. Simferopol: Scientific Production Association for essential oil crops and oils of the All-Union Research Institute of Aromatic Crops (VNIIEMK, 1977)

14. A. Karpacheva, K. Persidskaya, L. Lishtvanova, Biochemical methods of analysis essential oil crops and essential oil: collection of proceedings, Compiled by Simferopol: Ministry of Agriculture of the USSR, Scientific Production Association for essential oil crops and oils of the All-Union Research Institute of Aromatic Crops (VNIIEMK, 1972)

15. GOST ISO 7609-2014. Essential oils. Gas chromatography analysis on capillary columns. General method. Access mode: http://meganorm.ru/Data2/1/4293768/4293 768497.pdf (access date 30.09.2017).

16. B. Dospekhov, Methodology for field trials (with the basics of statistical processing of research results). (M., 2012)

17. S. Voitkevich, Essential oils for perfumes and aromatherapy (M.: Food Industry, 1999)

18. A. Alizadeh, M. Shaabani, Adv. Environ. Biol., 6, 1 (2012)

19. N. Kovalenko, G. Supichenko, V. Leontiev, A. Shutova, A. Kulinchik, J. Chem. Technol. Biotechnol., 1, 4 (2010)

20. V. Rabotyagov, S. Kutko, Bull. Nikitsky Botanical Garden, 119 (2016).

21. J. Craft, I. Satya, W. Setzer, Med., 4 (2017)

22. ISO 9909:1997 Oil of Dalmatian sage (Salvia officinalis L.) oil of Dalmatian sage. URL: https://www.iso.org/standard/17791.html Access date - 10.08.2020 